\title{
Role of IL-10 in inhibiting protective immune responses against infection with heterologous Plasmodium parasites
}

\author{
Sayuri Nakamae $e^{\mathrm{a}, \mathrm{b}}$, Daisuke Kimura ${ }^{\mathrm{a}, \mathrm{c}, \mathrm{d}}$, Mana Miyakoda ${ }^{\mathrm{a}, \mathrm{c}, \mathrm{e}}$, Odsuren Sukhbaatar, ${ }^{\mathrm{a}, \mathrm{b}}$, \\ Shin-Ichi Inoue ${ }^{\mathrm{a}, \mathrm{c}}$, Katsuyuki Yui ${ }^{\mathrm{a}, \mathrm{b}, \mathrm{c}, \mathrm{f}, *}$ \\ ${ }^{a}$ Division of Immunology, Department of Molecular Microbiology and Immunology, Graduate School of Biomedical Sciences, Nagasaki University, 1-12-4 Sakamoto, \\ Nagasaki 852-8523, Japan \\ ${ }^{\mathrm{b}}$ Program for Nurturing Global Leaders in Tropical and Emerging Infectious Diseases, Graduate School of Biomedical Sciences, Nagasaki University, 1-12-4 Sakamoto, \\ Nagasaki 852-8523, Japan \\ ${ }^{\mathrm{c}}$ Department of Immunology, School of Medicine, Nagasaki University, 1-12-4 Sakamoto, Nagasaki 852-8523, Japan \\ ${ }^{\mathrm{d}}$ Department of Health, Sports, and Nutrition, Faculty of Health and Welfare, Kobe Women's University, 4-7-2 Minatojima-nakamachi, Chuo-ku, Kobe 650-0046, Japan \\ ${ }^{\mathrm{e}}$ Research and Education Center for Drug Fostering and Evolution, School of Pharmaceutical Sciences, Nagasaki University, 1-14 Bunkyomachi, Nagasaki 852-8521, \\ Japan \\ ${ }^{\mathrm{f}}$ Graduate School of Tropical Medicine and Global Health, Nagasaki University, 1-12-4 Sakamoto, Nagasaki 852-8523, Japan
}

\section{A R T I C L E I N F O}

\section{Keywords:}

Malaria

Protection

Pathogenesis

CD4 ${ }^{+} \mathrm{T}$ cells

IL-10

Heterologous parasites

Secondary response

\begin{abstract}
A B S T R A C T
Malaria is induced by infection with Plasmodium parasites, which are genetically diverse, and the immune response to Plasmodium infection has both allele-specific and cross-reactive components. To determine the role of the cross-reactive immune response in the protection and disease manifestation in heterologous Plasmodium infection, we used infection models of $P$. chabaudi chabaudi (Pcc) and P. berghei ANKA (PbA). CD4 ${ }^{+}$T cells primed with Pcc infection exhibited strong cross-reactivity to PbA antigens. We infected C57BL/6 mice with Pcc and subsequently treated them with an anti-Plasmodium drug. The Pcc-primed mice exhibited reduced parasitemia and showed no signs of experimental cerebral malaria after infection with PbA. CD4 ${ }^{+} \mathrm{T}$ cells from the Pcc-primed mice produced high levels of IFN- $\gamma$ and IL-10 in response to PbA early after PbA infection. The blockade of IL-10 signaling with anti-IL-10 receptor antibody increased the proportion of activated CD4 ${ }^{+}$and $\gamma \delta$ $\mathrm{T}$ cells and the IFN- $\gamma$ production by $\mathrm{CD}^{+}{ }^{+} \mathrm{T}$ cells in response to $\mathrm{PbA}$ antigens, while markedly reducing the levels of parasitemia. In contrast, IL-10 blockade did not have a significant effect on parasitemia levels in unprimed mice after $\mathrm{PbA}$ infection. These data suggest a potent regulatory role of $\mathrm{IL}-10$ in the cross-reactive memory response to the infection with heterologous Plasmodium parasites leading to the inhibition of the protective immunity and pathogenesis.
\end{abstract}

\section{Introduction}

Malaria is a life-threatening disease caused by Plasmodium parasites and is one of the most important infectious diseases worldwide: WHO estimated 219 million cases of malaria and 435,000 malaria-related deaths in 2017 [1]. An increasing body of evidence indicates that $\mathrm{T}$ and B cell immune responses are pivotal for the protection against bloodstage infection with Plasmodium parasites [2-4]. CD4 ${ }^{+}$T cells produce cytokines including IFN- $\gamma$, which activate macrophages and stimulate B cells to become plasma cells that produce protective antibodies [5]. Mice with IFN- $\gamma$ or its receptor knocked out and those treated with antiIFN- $\gamma$ antibody have been shown to have defects in controlling Plasmodium infection [6], indicating that IFN- $\gamma$ plays a pivotal role in the protective immunity against blood-stage Plasmodium infection. However, the immune response incurs collateral damage to the host tissues when it is not well controlled; in fact, much of the pathology associated with malaria is considered to be caused by the immune response $[4,7,8]$. In the mouse model of experimental cerebral malaria (ECM), infection of C57BL/6 (B6) mice with $P$. berghei ANKA (PbA) induces cerebral disease at peripheral blood parasitemia levels that are not high enough to induce pathology in other strains of Plasmodium parasites $[9,10]$. Studies suggest that brain-infiltrating $\mathrm{CD}^{+} \mathrm{T}$ cells play a critical role in the pathogenesis of ECM and that IFN- $\gamma$-producing CD4 ${ }^{+} \mathrm{T}$ cells promote the disease [11-13]. Thus, adaptive immune responses against blood-stage infection with Plasmodium parasites could be simultaneously protective and pathogenic for the host.

\footnotetext{
* Corresponding author at: Department of Immunology, School of Medicine, Nagasaki University, 1-12-4 Sakamoto, Nagasaki 852-8523, Japan.

E-mail address: katsu@nagasaki-u.ac.jp (K. Yui).
} 
Plasmodium parasites are genetically diverse and multiple species and strains can infect humans in malaria-endemic areas [14]. The immune response induced by natural infection can target various Plasmodium antigens; the immune response thus has species- and strainspecific components $[15,16]$. Experimentally, the immune response to infection with parasites belonging to species or strains different from the ones causing the previous infection is less pronounced, suggesting the species and strain-specific nature of anti-malarial immune response $[4,7,17,18]$. In addition, vaccine trials of blood-stage candidate antigens suggested that the efficacy of vaccination was reduced with nonvaccine type parasites and thus has allele-specific components [3] [19]. However, other studies suggested that the immune response to Plasmodium infection has a cross-reactive component: e.g., immunity induced by subpatent blood-stage infection with Plasmodium chabaudi chabaudi AS (Pcc) induced anti-P. chabaudi IgG antibody production and $\mathrm{T}$ cell response that were protective against subsequent challenge infection with homologous parasites as well as the heterologous $P$. chabaudi chabaudi CB [20]; and mice immunized with attenuated Pcc were protected against challenge infection with heterologous parasites, $P$. vinckei and $P$. yoelii [21]. Taken together, these studies suggest that both allele-specific and cross-reactive components exist in the immune response against Plasmodium infection.

People living in the malaria-endemic region obtain resistance to disease manifestations after repeated infections [7]. However, individuals acquire only partial protection, partly because the immune response to Plasmodium parasites has an allele-specific component [19]. In addition, the immune response may modify disease manifestations caused by subsequent infection with heterologous Plasmodium parasites.

In this study, we investigated the effect of cross-reactive immune response induced by prior infection with Plasmodium parasites on the protection against and the manifestation of subsequent infection with heterologous parasites. We used Pcc for priming, which is often used as a model of $P$. falciparum because it invades both normocytes and reticulocytes, and the infected red blood cells (RBCs) adhere to host endothelial cells [22]. In addition, T cells play a major role in the protective immunity against Pcc infection, and memory $\mathrm{T}$ cells convey protection against subsequent challenge infection with homologous parasites [23,24].

\section{Material and methods}

\subsection{Animals and Plasmodium parasites}

B6 mice were purchased from SLC (Shizuoka, Japan). Mice were used at $6-10$ weeks of age. The animal experiments were approved by the Institutional Animal Care and Use Committee of Nagasaki University and were conducted according to the guidelines for Animal Experimentation at Nagasaki University.

Pcc was provided by Dr. R. Culleton (Nagasaki University, Nagasaki, Japan). PbA and PbA expressing GFP (PbA-GFP) [25] was provided by Dr. M. Yuda (Mie University, Tsu, Japan). Mice were infected intraperitoneally with parasitized RBCs $\left(5 \times 10^{4}\right)$. The levels of parasitemia were determined by microscopic examination of standard thin blood smears stained with a Diff-Quik staining kit (Sysmex, Kobe, Japan) for Pcc and PbA. When mice were infected with PbA-GFP, the parasitemia levels were determined using FACSCanto II (BD Biosciences, Franklin Lakes, NJ, USA).

For the drug treatment, starting at 6 or 14 days after infection with Pcc, mice were intraperitoneally given chloroquine $(10 \mu \mathrm{g} / \mathrm{g}$ weight; Sigma-Aldrich) in PBS for 7 consecutive days and sulfadiazine $(30 \mathrm{mg} /$ L; Sigma-Aldrich) in drinking water for 14 or 10 days (experiments in Fig. 6). Mice were monitored daily, starting on day 4 of the infection, or every second day after day 5 of infection. After infection with $\mathrm{PbA}$, the clinical scores were defined by the presence of the typical pathological signs, as described previously [26]: ruffled fur, hunching, wobbly gait, limb paralysis, convulsions, and coma; each sign was given a score of 1 . To block IL-10 signaling, mice received anti-IL-10R mAb ( $400 \mu \mathrm{g}$; 1B1-3A; Bio X cell, West Lebanon, NH, USA) or rat IgG (400 $\mu$ g; SigmaAldrich, St. Louis, MO, USA) in PBS intraperitoneally every 2 days, starting at the time of infection with $\mathrm{PbA}$ or PbA-GFP.

\subsection{Assessment of the integrity of the blood-brain barrier}

Seven days after infection with $\mathrm{PbA}$ or Pcc, mice were injected intravenously with $200 \mu \mathrm{L}$ of Evans Blue (2\%; Wako, Osaka, Japan) in PBS. One hour later, the mice were anesthetized and perfused with $15 \mathrm{~mL}$ of cold PBS. After sacrifice, brains were isolated, and Evans Blue was extracted by incubating in $2 \mathrm{~mL}$ PBS containing $4 \%$ paraformaldehyde, at room temperature, for $48 \mathrm{~h}$. The supernatant was collected, and the absorbance was read at $600 \mathrm{~nm}$ using a densitometer (Biochrom WPA CO8000 Cell density meter; Biochrom, Cambridge, UK).

\subsection{Flow cytometry}

Spleen cells were treated with Gey's solution to lyse erythrocytes and were stained for cell surface molecules with the following monoclonal antibodies for $30 \mathrm{~min}$ at $4^{\circ} \mathrm{C}$ : BV510-anti-CD3 (17A2), APCCy7anti-CD3, BV711-anti-CD4 (RM4-5), PECy7-anti-CD4 (RM4-5), APCCy7-anti-CD4 (GK1.5), APCCy7-anti-CD8 (53-6.7), FITC-antiCD11a (M17/4), PE-anti-CD49d (R1-2), FITC-anti-CD44 (IM7), PEanti-CD62L (MEL-14), PECy7-anti-CD19 (eBio1D3), BV650-anti-B220 (RA3-6B21), APC-anti-B220, Alexa Fluor 488-anti-NK1.1 (PK136), PEanti-TCR $\gamma \delta$ (GL3), and APC-anti- $\gamma \delta$ TCR mAb. Staining was performed with biotin-anti-CD62L (MEL-14) monoclonal antibodies, followed by incubation with PE-streptavidin. All antibodies were purchased from Biolegend (San Diego, CA, USA), Tonbo Biosciences (San Diego, CA, USA), or eBioscience (San Diego, CA, USA). To exclude dead cells from the analysis, 7-aminoactinomycin D (7-AAD) was added prior to the analysis. For intracellular staining, splenocytes were stained with PECy5-anti-CD3 (145-2C11), BV510-anti-CD3(17A2), APC-anti-CD4 (GK1.5), and FITC-anti-CD25 (PC61.5) monoclonal antibodies for $30 \mathrm{~min}$ at $4{ }^{\circ} \mathrm{C}$, fixed and permeabilized using Foxp3 / Transcription Factor Staining Buffer set (eBioscience), and stained with PECy7- or PEanti-Foxp3 (FJK-16s) monoclonal antibodies. The stained cells were analyzed using FACSCanto II or LSRFortessa X-20 cell analyzer (BD Biosciences) and FlowJo software (Tree Star, Ashland, OR, USA).

\subsection{Cell culture and ELISA}

$\mathrm{CD}^{+} \mathrm{T}$ cells were enriched (>95\%) from the spleen using antiCD4 IMag (BD Biosciences) according to the manufacturer's instructions. Cells were suspended in RPMI-1640 medium supplemented with $10 \%$ heat-inactivated fetal calf serum (FCS), $2 \mathrm{mM}$ glutamine, penicillin/streptomycin, 2-mercaptoethanol $\left(5 \times 10^{-5} \mathrm{M}\right)$, non-essential amino acids $(0.1 \mathrm{mM})$, and sodium pyruvate $(1 \mathrm{mM})$. To examine antigen-specific responses, CD4 ${ }^{+} \mathrm{T}$ cells $\left(2 \times 10^{5}\right)$ were cultured in 96well flat-bottom plates in the presence of dendritic cells $\left(1 \times 10^{4}\right)$ with or without Pcc or PbA crude antigen (freeze-thaw lysate of $5 \times 10^{6}$ infected RBCs) for 2 days.

The levels of IFN- $\gamma$, IL-2, and IL-10 in the culture supernatant were determined by sandwich ELISA using anti-IFN- $\gamma$ (R4-6A2; Biolegend) and biotin-anti-IFN- $\gamma$ (XMG1.2; eBioscience), anti-IL-2 (JES6-1A12; Biolegend) and biotin-anti-IL-2 (JES6-5H4; eBioscience), and anti-IL-10 monoclonal antibodies (Ready SET Go! Kit, eBioscience), respectively, as described previously [27].

The levels of anti-Pcc or -PbA IgG1, IgG2b, and IgG2c antibodies in sera were determined by ELISA. ELISA plates were coated with freeze-thaw lysate of Pcc or PbA $\left(1 \times 10^{6}\right.$ infected RBCs/well $)$ in PBS at room temperature for $2 \mathrm{~h}$. Coated plates were washed with PBS containing $0.2 \%$ Tween 20 (washing buffer) and blocked with PBS 
containing $10 \%$ FCS for $30 \mathrm{~min}$ at room temperature. After washing, serum ( $80 \times$ dilution) was added, and plates were incubated overnight at $4{ }^{\circ} \mathrm{C}$. The plates were washed, incubated with biotin-conjugated rabbit anti-mouse IgG1 or IgG2b antibodies (ZyMED, San Francisco, CA, USA) or biotin-conjugated rabbit anti-mouse IgG2c antibodies (BETHYL Laboratories, Montgomery, TX, USA) for $1 \mathrm{~h}$, washed, and incubated with alkaline phosphatase-conjugated streptavidin (Jackson ImmunoResearch, West Grove, PA, USA) for $30 \mathrm{~min}$. After washing, $1 \mathrm{mg} / \mathrm{mL}$ solution of 4-nitrophenyl phosphate disodium salt hexahydrate (Sigma-Aldrich) in distilled water was added to each well, and the absorbance was read at $405 \mathrm{~nm}$ using an iMark Microplate Absorbance Reader (BIO-RAD, Hercules, CA, USA).

\subsection{Statistical analysis}

For comparisons between two groups, two-tailed unpaired Student's $t$-tests was used. When three or more groups were compared, an overall difference between the groups was determined using one-way ANOVA or two-way ANOVA for cytokine production analysis. When one-way or two-way ANOVA was significant, differences between individual groups were estimated using Bonferroni's test.

\section{Results}

\subsection{Cross-reactivity of $\mathrm{CD}^{+}{ }^{+} \mathrm{T}$ cells from Pcc-primed mice to heterologous $\mathrm{PbA}$ antigens}

To determine the cross-reactive response of $\mathrm{CD}^{+}{ }^{+} \mathrm{T}$ cells against Plasmodium antigens of different species, B6 mice were infected with Pcc, and IFN- $\gamma$ production of splenic $\mathrm{CD}^{+}{ }^{+} \mathrm{T}$ cells in response to crude Pcc and PbA antigens was determined 7 days later. CD4 ${ }^{+}$T cells from Pcc-primed mice produced IFN- $\gamma$ in response to PbA antigens, although the levels were approximately half of those produced in response to Pcc antigens (Fig. 1A). Similarly, PbA-primed CD $4^{+} \mathrm{T}$ cells produced IFN- $\gamma$ in response to Pcc antigens at levels slightly less than those in response to $\mathrm{PbA}$ antigens (Fig. S1). These results indicated that $\mathrm{CD}^{+}{ }^{+} \mathrm{T}$ cells from mice infected with Plasmodium parasites exhibit strong cross-reactive responses against heterologous Plasmodium antigens.

To determine whether the cross-reactive responses are maintained in memory $\mathrm{T}$ cells in the absence of active infection, B6 mice were infected with Pcc and were treated with an anti-malaria drug, chloroquine or sulfadiazine, starting at 14 days after infection (Fig. 1B). $>2$ weeks after termination of the treatment, the immune response of splenic $\mathrm{CD} 4^{+} \mathrm{T}$ cells was evaluated (Fig. 1C, D, Fig. S2, S3). The proportions of $\mathrm{CD}^{+}$and $\mathrm{CD}^{+}{ }^{+} \mathrm{T}$ cells, B cells, NK cells, and regulatory $\mathrm{T}$ (Treg) cells in the spleen of Pcc-primed mice were not significantly different from those in uninfected mice, while the proportion of $\gamma \delta \mathrm{T}$ cells was increased (Fig. 1C). The upregulation of integrins CD11a and CD49d is often used as a surrogate marker of antigen-specifically activated $\mathrm{CD}^{+}{ }^{+} \mathrm{T}$ cells $[28,29]$. The proportion of specific CD11 $\mathrm{a}^{\text {hi }} \mathrm{CD} 49 \mathrm{~d}^{\text {hi }} \mathrm{CD} 4{ }^{+} \mathrm{T}$ cells in Pcc-primed mice was not significantly different from that in uninfected mice, while the proportion of both effector memory (CD44 ${ }^{\text {hi }}$ CD62 $\mathrm{L}^{\text {lo }}$ ) and central memory $\left(\mathrm{CD} 44^{\mathrm{hi}} \mathrm{CD} 2 \mathrm{~L}^{\mathrm{hi}}\right) \mathrm{CD}^{+}{ }^{+} \mathrm{T}$ cells and $\mathrm{CD} 25^{+} \mathrm{Foxp}^{-} \mathrm{CD}^{+} \mathrm{T}$ cells was increased (Fig. 1C). Coordinate upregulation of CD11a and downregulation of $\mathrm{CD} 8 \alpha$ is used to define antigen-specific $\mathrm{CD} 8^{+} \mathrm{T}$ cells [29]. The proportion of activated (CD11 $\left.\mathrm{a}^{\text {hi }} \mathrm{CD} 8 \alpha^{\text {lo }}\right) \mathrm{CD}^{+} \mathrm{T}$ cells and central memory (CD44 ${ }^{\mathrm{hi}} \mathrm{CD} 62 \mathrm{~L}^{\mathrm{hi}}$ ) $\mathrm{CD} 8^{+} \mathrm{T}$ cells in Pcc-primed mice was not significantly different from that in uninfected mice, while the proportion of effector memory $\left(\mathrm{CD} 44^{\mathrm{hi}} \mathrm{CD} 62 \mathrm{~L}^{\mathrm{lo}}\right) \mathrm{CD} 8^{+} \mathrm{T}$ cells was increased (Fig. 1C). CD4 ${ }^{+}$T cells from Pcc-primed mice produced IFN- $\gamma$, IL-2, and IL-10 in response to not only to Pcc antigens, but also PbA antigens (Fig. 1D), indicating that the cross-reactive memory response of $\mathrm{CD}^{+}$ $\mathrm{T}$ cells to $\mathrm{PbA}$ antigens was maintained $>1$ month after treatment. In the serum of these mice, IgG1, IgG2b, and IgG2c antibodies specific for Pcc antigens were detected, and IgG2b and IgG2c antibodies exhibited cross-reactivity to $\mathrm{PbA}$ antigens (Fig. 1E). These results imply that memory $\mathrm{CD}^{+}{ }^{+} \mathrm{T}$ and $\mathrm{B}$ cells cross-reactive to $\mathrm{PbA}$ antigens are induced and maintained after Pcc infection followed by treatment.

\subsection{Modulation of the immune pathology induced by $P b A$ infection in Pcc- primed mice}

We next evaluated the effect of cross-reactive immune response on disease manifestation in subsequent challenge infections. B6 mice were infected with Pcc, treated with anti-Plasmodium drugs for 14 days, and infected with $\mathrm{PbA}$ after additional 16-27 days (Fig. 2). Control unprimed mice exhibited increased parasitemia and succumbed to death due to ECM 8-10 days after PbA-infection. However, Pcc-primed mice exhibited low levels of parasitemia up to 9 days after $\mathrm{PbA}$ infection, did not develop symptoms of ECM or weight loss, and did not succumb to death; however, they did show increased parasitemia after 10 days of the infection and maintained high levels of parasitemia; therefore, they were sacrificed 20-30 days after the infection (Fig. 2A). To determine the integrity of the blood-brain barrier, mice were injected with Evans Blue 7 days after $\mathrm{PbA}$ infection. As positive and negative controls, naïve mice were infected with PbA or Pcc, respectively. Brains of Pcc-primed mice excluded the dye after $\mathrm{PbA}$ infection, while those of unprimed mice did not, indicating that the integrity of blood-brain barrier was maintained in the primed mice (Fig. 2B). These data suggest that the immune response is modulated in Pcc-primed mice and hinders the development of ECM after the infection with PbA.

We thus examined the immune response of these mice more in detail. Pcc-primed and unprimed control mice were infected with PbA, and $\mathrm{T}$ cell responses were evaluated 3 and 7 days later (Fig. 3A). No significant differences were detected in the proportions of CD11 $\mathrm{a}^{\text {hi }} \mathrm{CD} 49 \mathrm{~d}^{\mathrm{hi}}$ and $\mathrm{CD} 44^{\mathrm{hi}} \mathrm{CD} 62 \mathrm{~L}^{\text {lo }} \mathrm{CD} 4{ }^{+} \mathrm{T}$ cells and $\mathrm{CD} 11 \mathrm{a}^{\mathrm{hi}} \mathrm{CD} 8 \alpha^{\text {lo }}$ and $\mathrm{CD} 44^{\mathrm{hi}} \mathrm{CD} 62 \mathrm{~L}^{\text {lo }} \mathrm{CD} 8^{+} \mathrm{T}$ cells 3 and 7 days after infection with $\mathrm{PbA}$ (Fig. 3B, C, S4). The proportion of $\gamma \delta \mathrm{T}$ cells, which was higher in Pccprimed mice (Fig. 1C), remained high 7 days after infection with $\mathrm{PbA}$, while that of B cells decreased (Fig. 3C). We compared cytokine production by $\mathrm{CD}^{+}{ }^{+} \mathrm{T}$ cells from unprimed and Pcc-primed mice in response to Pcc and $\mathrm{PbA}$ antigens 3 and 7 days after infection with $\mathrm{PbA}$ (Fig. 3D, E). CD4 ${ }^{+}$T cells from Pcc-primed mice produced both IFN- $\gamma$ and IL-10, but not IL-2, in response to PbA antigens at levels much higher than those from unprimed mice 3 days after $\mathrm{PbA}$ infection, suggesting that cross-reactive memory $\mathrm{CD}^{+}{ }^{+} \mathrm{T}$ cells were activated by PbA-infection (Fig. 3D). However, 7 days after infection, $\mathrm{CD}^{+}{ }^{+} \mathrm{T}$ cells from the primed mice produced IFN- $\gamma$ in response to $\mathrm{PbA}$ antigens at levels lower than those from unprimed mice, while they produced IL-10 at similar levels (Fig. 3E). These results suggest that $\mathrm{CD} 4^{+} \mathrm{T}$ cells from Pcc-primed mice exhibited an early recall IFN- $\gamma$ response to PbA antigens, although this response was not sustained after infection, while the IL-10 response was maintained at high levels.

\subsection{The effect of $I L-10$ on challenge infection with heterologous Plasmodium parasites}

Since the recall IFN- $\gamma$ response of $\mathrm{CD}^{+}{ }^{+} \mathrm{T}$ cells was not sustained in Pcc-primed mice after challenge infection with $\mathrm{PbA}$, we hypothesized that IL-10 produced by $\mathrm{CD} 4{ }^{+} \mathrm{T}$ cells modulated the $\mathrm{T}$ cell response. To evaluate the role of IL-10 in the recall response of $\mathrm{CD}^{+}{ }^{+} \mathrm{T}$ cells, $\mathrm{IL}-10$ signaling was blocked in vivo by administration of anti-IL-10R antibodies after challenge infection with $\mathrm{PbA}$ (Fig. 4A). The levels of parasitemia did not increase in IL-10-blocked Pcc-primed mice until 11 days after $\mathrm{PbA}$ infection, while they increased in control Pcc-primed mice after 8 days of $\mathrm{PbA}$ infection (Fig. 4B). The IL-10-blocked mice exhibited severer loss of body weight and clinical symptoms, suggesting the pathology was mediated by the immune system. When we observed these mice for a longer period, 3 out of 5 mice survived both among the IL-10-blocked and the Pcc-primed IgG-treated mice and exhibited very low $(0.06 \pm 0.01 \%)$ and high $(48.3 \pm 25.6 \%)$ parasitemia at 28 days 
A

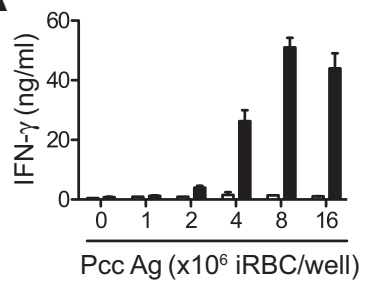

C

$\mathrm{CD4}^{+} \mathrm{T}$ cells
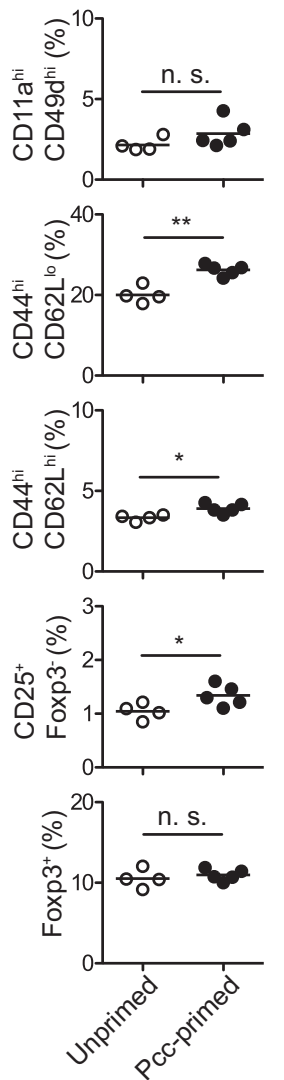

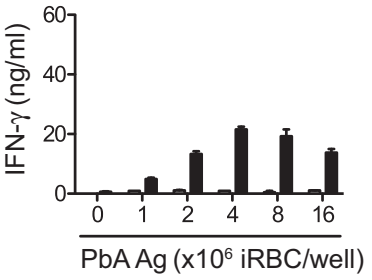

B

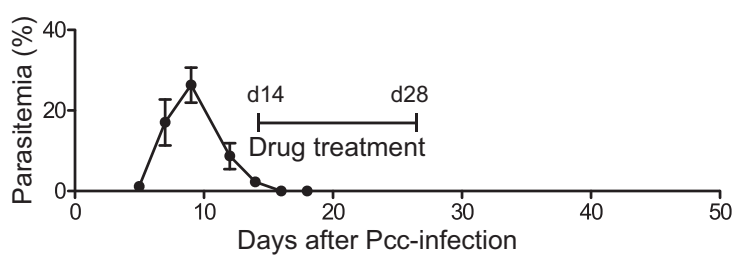

D
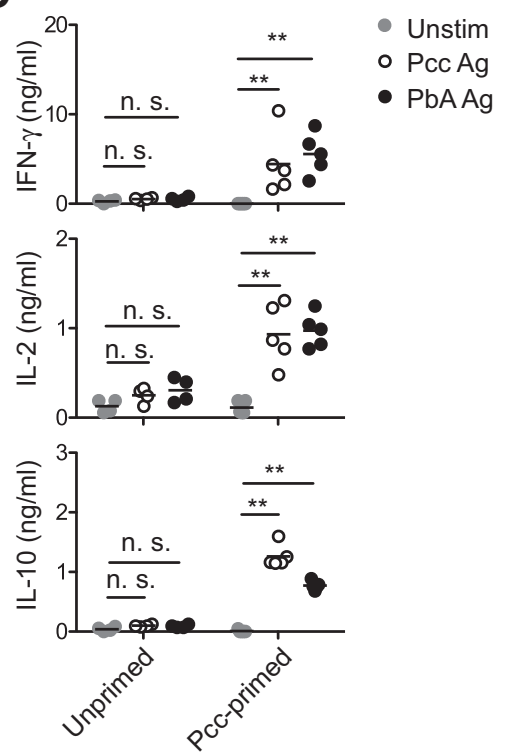

E

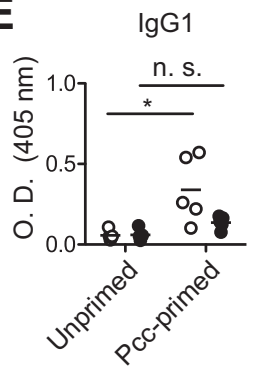

$\lg \mathrm{G} 2 \mathrm{c}$
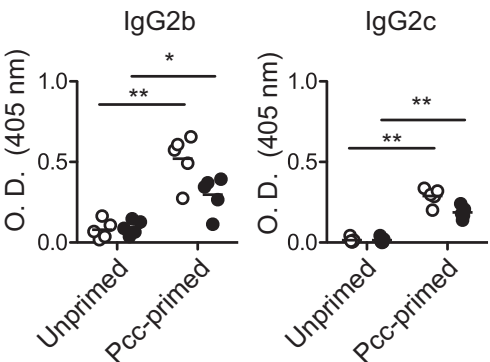

- Pcc Ag

- $\mathrm{PbAAg}$
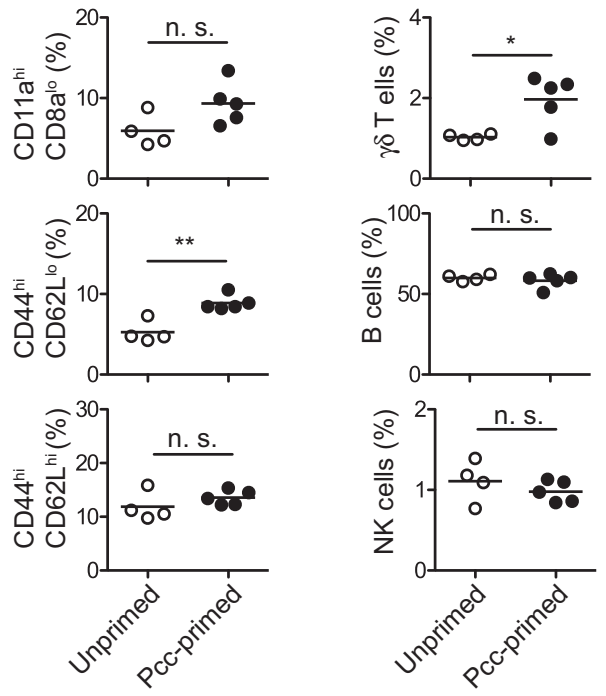

Fig. 1. $\mathrm{CD} 4^{+} \mathrm{T}$ cell response in mice infected with heterologous malaria antigens. (A) Splenic $\mathrm{CD} 4^{+} \mathrm{T}$ cells from uninfected mice (open bar) or mice infected with Pcc for 7 days (closed bar) were stimulated with dendritic cells and different doses of Pcc (left) or PbA (right) crude antigens for 2 days. The levels of IFN- $\gamma$ in the supernatants were determined by ELISA. Data are presented as mean values \pm SEM. (B-E) Mice were infected with Pcc, treated with chloroquine and sulfadiazine between 14 and 28 days after the infection. (B) The parasitemia levels were determined. The graph shows mean parasitemia values \pm SEM. (C) Spleen cells were prepared 43 days after infection, and their surface phenotypes were evaluated using flow cytometry. Statistical assessment was performed by unpaired Student's $t$ test. * $P<.05 ; * * P<.01$; n.s., not significant. (D) Purified CD4 ${ }^{+} \mathrm{T}$ cells were stimulated without (gray circle) and with Pcc (open circle) or PbA (closed circle) antigens for 2 days in the presence of dendritic cells, and the cytokine levels in the supernatant were determined by ELISA. Data are presented as mean values \pm SEM. Statistical assessment was performed by two-way ANOVA followed by Bonferroni's test. $* * \mathrm{P}<0.01$; n.s., not significant. (E) Representative data of 4 similar results are shown. Sera were collected from mice $(n=5) 43$ days after infection, and the levels of Pcc- (open circle) or PbA-specific (closed circle) IgG1, IgG2b, and IgG2c antibodies were determined by ELISA. Data are presented as mean values \pm SEM. Statistical assessment was performed by one-way ANOVA followed by Bonferroni's test. ${ }^{*} \mathrm{P}<0.05 ; * * \mathrm{P}<0.01 ;$ n.s., not significant.

after infection, respectively, supporting the notion that the parasitemia was better controlled in IL-10-blocked mice. Seven days after the challenge infection with $\mathrm{PbA}$, the immune response of these mice was examined. The proportion of $\mathrm{CD}^{+}$and $\mathrm{CD}^{+}{ }^{+} \mathrm{T}$ cells was not significantly different in IL-10-blocked mice than in the controls, while the proportion of $\gamma \delta \mathrm{T}$ cells and B cells increased, and that of NK cells decreased (Fig. S5A, 4C). The proportion of $\mathrm{CD} 11 \mathrm{a}^{\text {hi }} \mathrm{CD} 49 \mathrm{~d}^{\text {hi }}$ cells and $\mathrm{CD} 25^{+}$Foxp $^{-} \mathrm{CD}^{+} \mathrm{T}$ cells increased in IL-10-blocked mice, suggesting that clonal expansion of specific $\mathrm{CD} 4^{+} \mathrm{T}$ cells was enhanced; the proportion of $\mathrm{CD}^{+} \mathrm{T}$ cells was not increased (Fig. 4C). $\mathrm{CD}^{+} \mathrm{T}$ cells from IL-10-blocked mice exhibited IFN- $\gamma$ production in response to
Pcc and PbA antigens at levels higher than those from control mice, although the levels of IL-2 production did not differ significantly (Fig. 4D). The levels of PbA-specific IgG1, IgG2b, and IgG2c were not significantly affected by IL-10 blockade (Fig. 4E). These results suggested that IL-10 inhibited clonal expansion and IFN- $\gamma$ production by Pcc-primed cross-reactive $\mathrm{CD} 4^{+} \mathrm{T}$ cells during the recall response to $\mathrm{PbA}$ challenge infection.

Since the blockade of IL-10 signaling had a significant effect on the outcome of PbA infection in Pcc-primed mice, we next evaluated the effect of IL-10 blockade in PbA infection in naïve mice (Fig. 5A). When naïve mice were infected with $\mathrm{PbA}$, no significant effects of the 
A
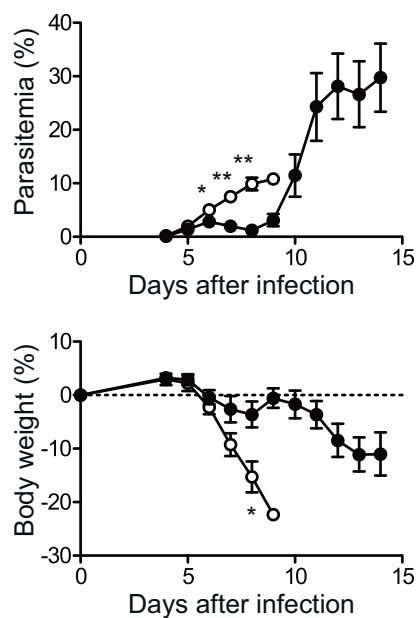
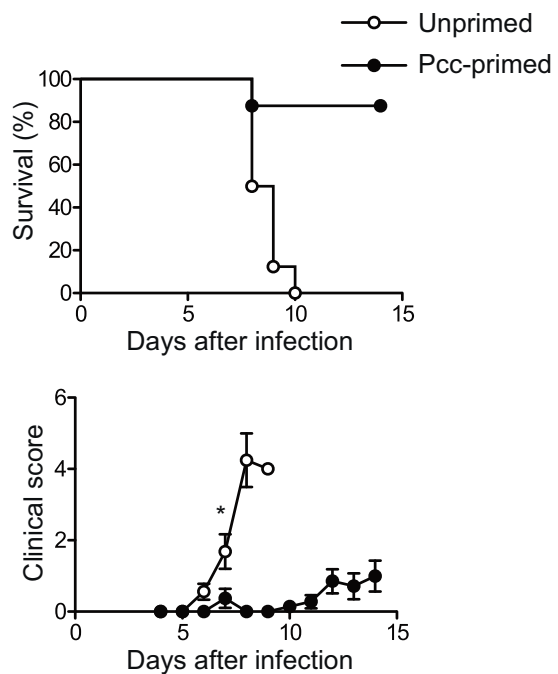

B

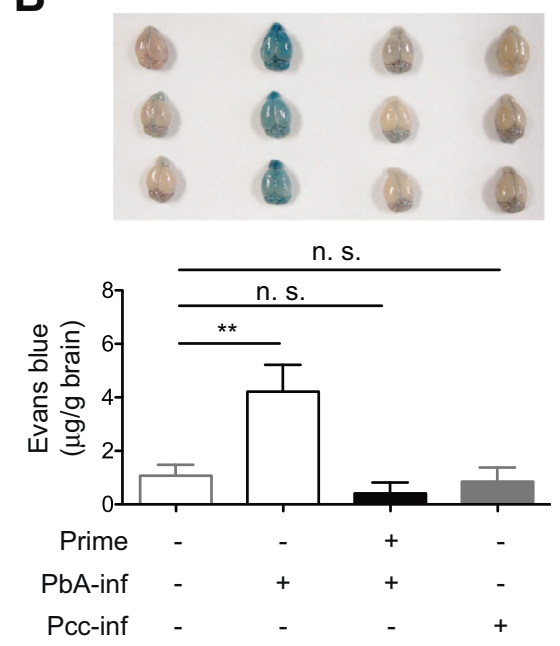

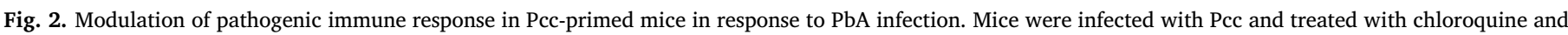

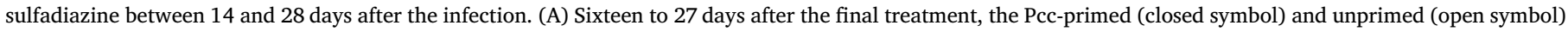

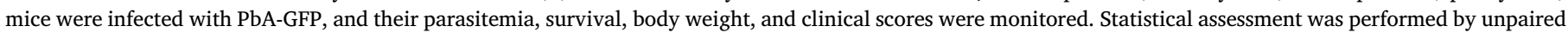

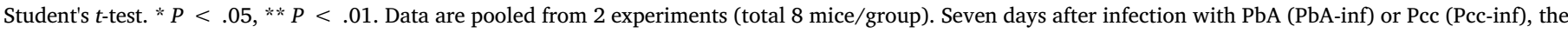

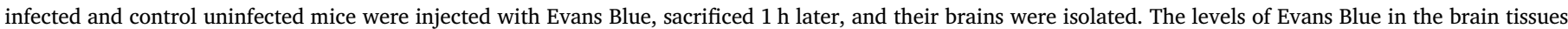

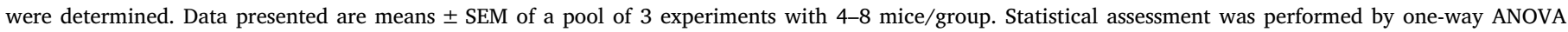

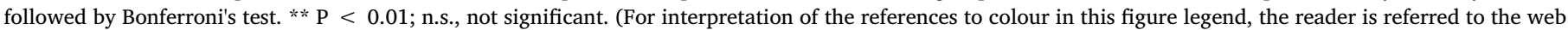
version of this article.)

blockade on the levels of parasitemia, clinical manifestations, or death were observed (Fig. 5B). However, the proportion of $\mathrm{CD} 25^{+} \mathrm{CD} 4{ }^{+} \mathrm{T}$ cells and $\mathrm{CD}^{+}{ }^{+} \mathrm{T}$ cells producing IFN- $\gamma$ in response to $\mathrm{PbA}$ antigens was higher in the blocked mice than in the control mice, suggesting that IL10 had an inhibitory effect on the activation of PbA-specific $\mathrm{CD}^{+} \mathrm{T}$ cells after infection in naïve mice (Fig. 5C, D). No significant effect was observed in the levels of $\gamma \delta$ T cells, B cells, NK cells, or PbA-specific antibodies. Taken together, while $\mathrm{CD} 4{ }^{+} \mathrm{T}$ cell activation was enhanced, IL-10 blockade did not have a significant impact on the clinical manifestations in mice primarily infected with $\mathrm{PbA}$.

\subsection{Priming of cross-reactive immunity occurs in a short period after Plasmodium infection}

We next examined the length of time required to gain cross-reactive immunity to the subsequent infection with $\mathrm{PbA}$. Mice were infected with Pcc and treated with anti-Plasmodium drugs for 10 days starting 6 or 14 days after infection (Fig. $6 \mathrm{~A}$ ). $>2$ months after the infection, the immune response of mice treated from day 6 and from day 14 was analyzed. The proportion of CD11 $\mathrm{a}^{\mathrm{hi}} \mathrm{CD} 49 \mathrm{~d}^{\mathrm{hi}}$ and CD44 ${ }^{\mathrm{hi}} \mathrm{CD} 62 \mathrm{~L}^{1 \mathrm{lo}} \mathrm{CD} 4^{+}$ $\mathrm{T}$ cells was not significantly different (Fig. 6B). CD4 ${ }^{+} \mathrm{T}$ cells from both groups produced IFN- $\gamma$, IL-2 and IL-10 at similar levels in response to both Pcc and PbA antigens (Fig. 6C). Moreover, the levels of IgG1, IgG2b, and IgG2c antibodies specific for Pcc and PbA antigens were similar in the two groups (Fig. 6D). When the mice were re-infected with Pcc, both groups exhibited limited parasitemia (Fig. 6E). When these mice were infected with $\mathrm{PbA}$, both groups exhibited a delayed onset of parasitemia and did not succumb to death due to ECM, although the mice treated since day 6 showed more severe clinical manifestations than the mice treated since day 14 (Fig. 6F). Taken together, the memory immune response against disease induced by heterologous Plasmodium infection was obtained as early as 6 days after Pcc infection, and anti-disease immunity was enhanced by the prolonged infection period.

\section{Discussion}

$\mathrm{CD}^{+}{ }^{+} \mathrm{T}$ cells primed by the infection with Pcc exhibited strong cross-reactivity to heterologous $\mathrm{PbA}$ antigens and produced IFN- $\gamma$, a cytokine critical for the protection against blood-stage Plasmodium infection $[5,6]$. We infected mice with Pcc and treated them with antiPlasmodium drugs for 14-28 days after infection to eliminate the residual parasites that could have affected the subsequent immune response to $\mathrm{PbA}$. The mice were then infected with heterologous $\mathrm{PbA}$ parasites. The results showed that these Pcc-primed mice did not develop ECM after infection with $\mathrm{PbA}$. This is likely due to the reduction of parasitemia 7-9 days after challenge infection with $\mathrm{PbA}$ and modulation of the immune response. Preexisting antibodies and cross-reactive memory $\mathrm{CD}^{+}{ }^{+} \mathrm{T}$ cells may have inhibited the parasitemia levels after PbA-infection. In particular, $\mathrm{CD}^{+}{ }^{+} \mathrm{T}$ cells from Pcc-primed $\mathrm{PbA}$ infected mice produced IFN- $\gamma$ and IL-10 at levels higher than unprimed mice on day 3 of the infection, suggesting that this response was mediated by memory $\mathrm{CD}^{+}{ }^{+} \mathrm{T}$ cells. However, 7 days after PbA-infection, IFN- $\gamma$ production by $\mathrm{CD} 4^{+} \mathrm{T}$ cells from the primed mice did not increase further, while IL-10 production continued to increase from day 3 to day 7. ECM is induced by a combination of parasitized RBCs that adhere to the brain endothelial cells and an inflammatory immune response that leads to the migration of pathogenic $\mathrm{CD} 8^{+} \mathrm{T}$ cells to the brain [30]. Injection of recombinant IL-10 has been shown to protect against ECM [31]. We suspect that both the reduction of parasitemia and the modulation of the immune responses in response to $\mathrm{PbA}$ infection, including the increased IL-10 production in Pcc-primed mice, contribute to the lack of ECM development in Pcc-primed mice in the present study.

IL-10 is a potent immunoregulatory cytokine and is crucial for the prevention of inflammatory pathologies. It suppresses antigen presentation and $\mathrm{T}$ cell activation mediated by dendritic cells and macrophages and inhibits the production of proinflammatory cytokines $[32,33]$. It also directly inhibits $\mathrm{T}$ cell proliferation and cytokine production [34]. While exhibiting levels of parasitemia similar to those of wild-type mice, IL-10 $0^{-/-}$mice infected with Pcc displayed more severe signs of disease, an increased death rate, and higher plasma levels of 
A

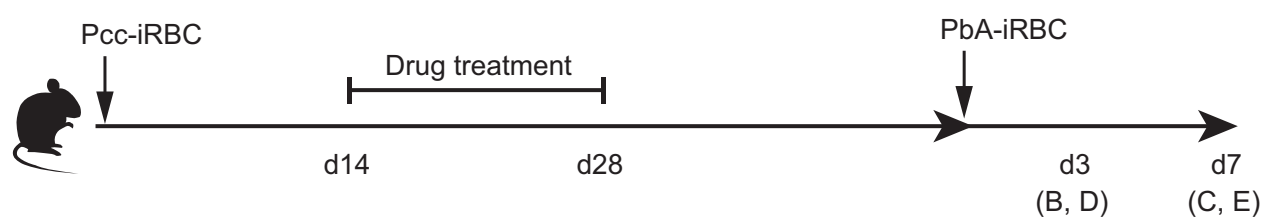

B

$$
\text { Day } 3
$$

CD4 ${ }^{+} \mathrm{T}$ cells
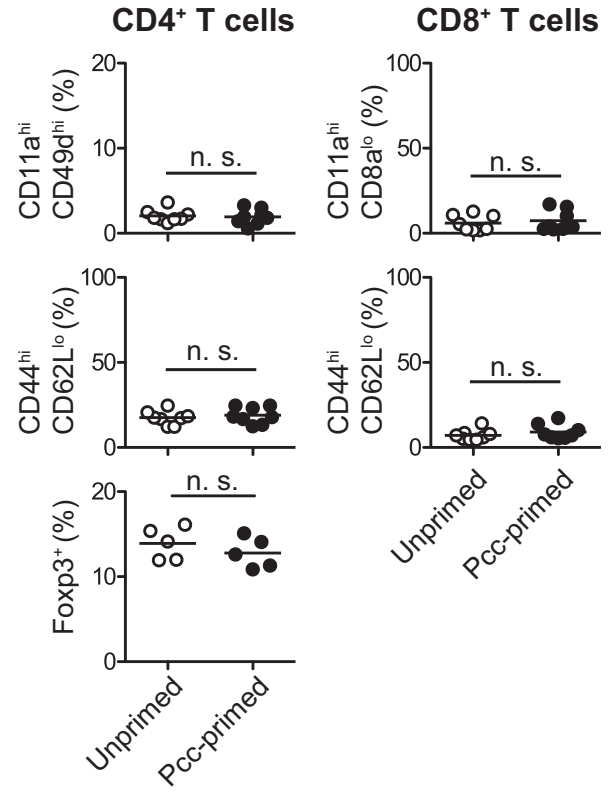

C Day 7
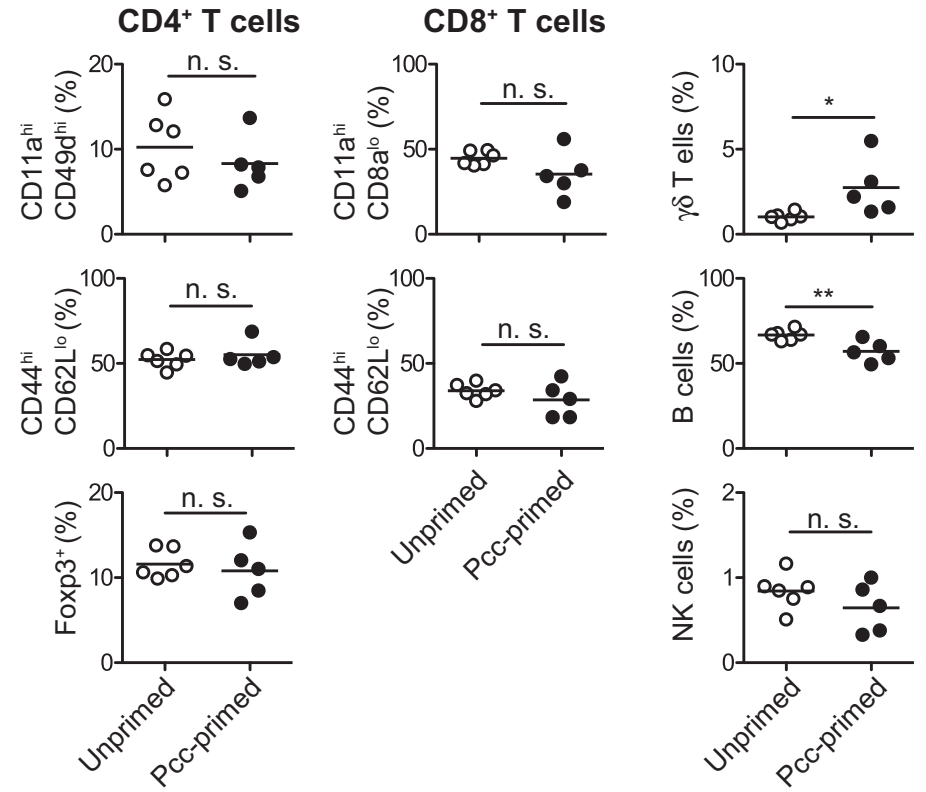

D Day 3
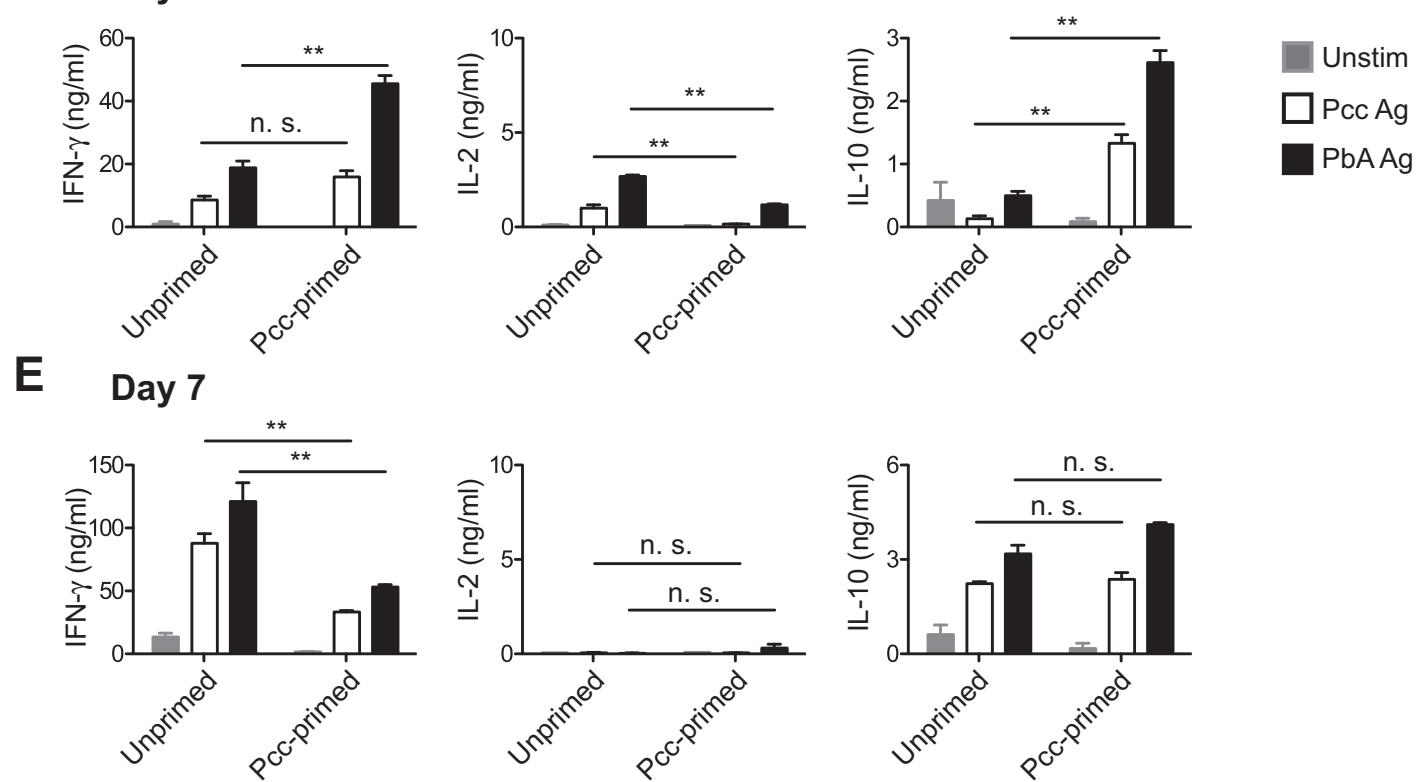

Fig. 3. $\mathrm{CD}^{+}{ }^{+}$T-cell responses of Pcc-primed mice in response to homologous and heterologous malaria antigens. Mice were infected (Pcc-prim) or uninfected (unprim) with Pcc and treated with chloroquine and sulfadiazine between 14 and 28 days after the infection. (A) Experimental scheme. After additional 17-87 days, both groups of mice were infected with $\mathrm{PbA}$, and their splenocytes were prepared 3 (B) or 7 (C) days after the infection, stained with antibodies, and analyzed using flow cytometry. The proportions of $\mathrm{CD}^{+}{ }^{+} \mathrm{T}$ cell subpopulations from unprimed and Pcc-primed mice are shown. Data are pooled from 4 (B) or 2 (C) experiments. Statistical assessment was performed unpaired Student's $t$-test. ${ }^{*} \mathrm{P}<0.05 ;{ }^{* *} \mathrm{P}<0.01$; n.s., not significant. $\mathrm{CD} 4{ }^{+} \mathrm{T}$ cells were prepared from unprimed and Pccprimed mice 3 (D) or 7 (E) days after infection with PbA and co-cultured with dendritic cells in the absence (gray bar) or presence of Pcc (open bar) or PbA (closed bar) antigens for 2 days. The levels of IFN- $\gamma$, IL-2, and IL-10 in the supernatants were determined by ELISA. Data presented are means \pm SEM. Statistical assessment was performed by two-way ANOVA followed by Bonferroni's test. ** $\mathrm{P}<.01$; n.s., not significant. Results are representative of 3 independent experiments. 

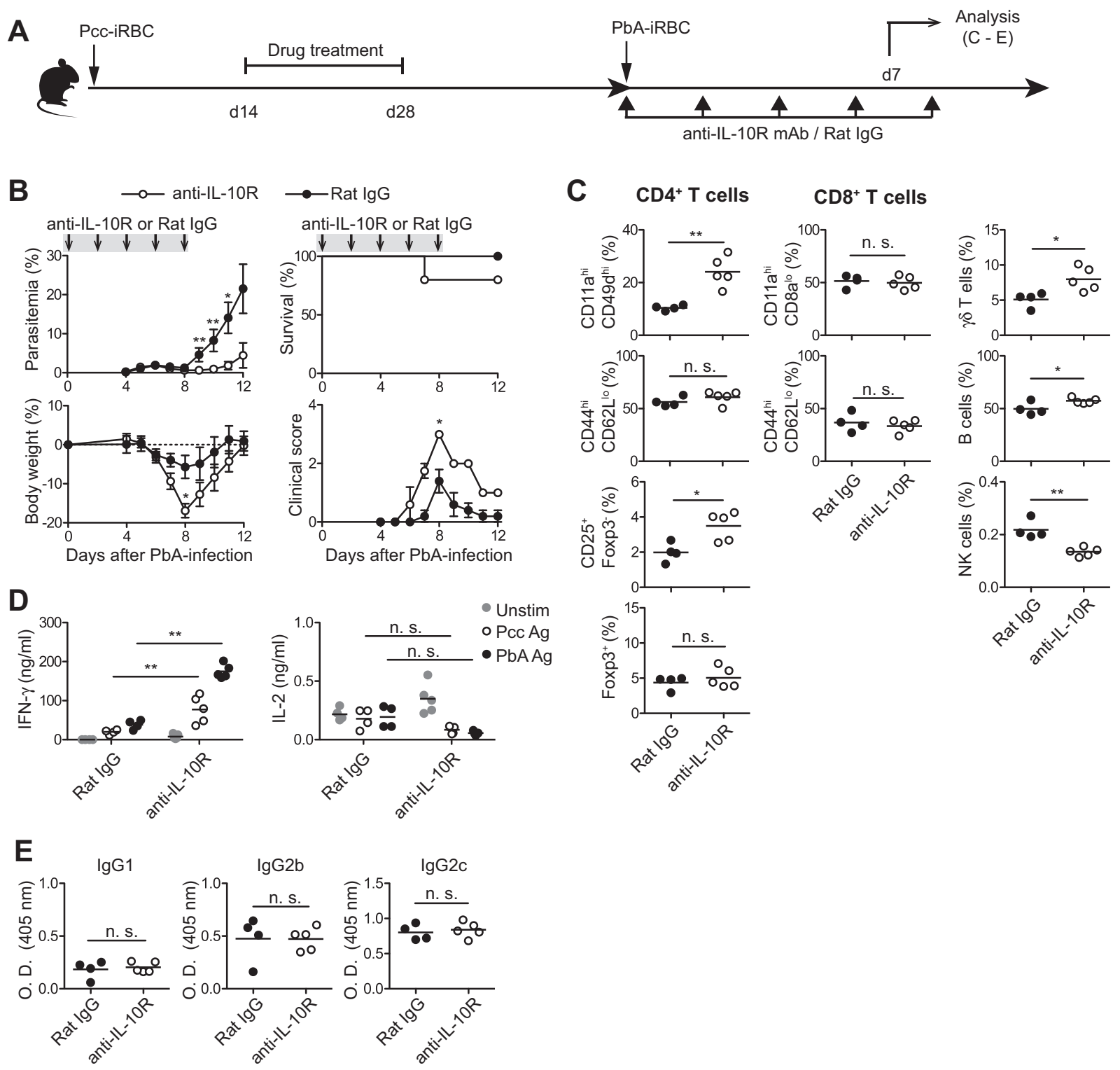

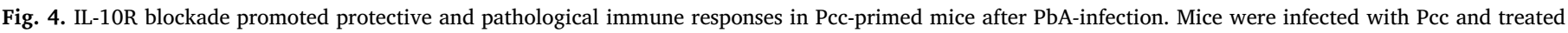

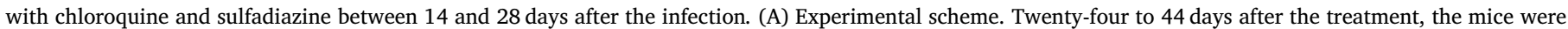

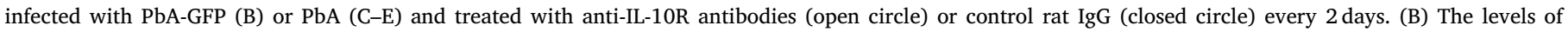

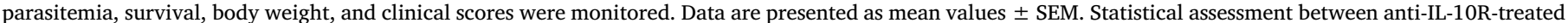

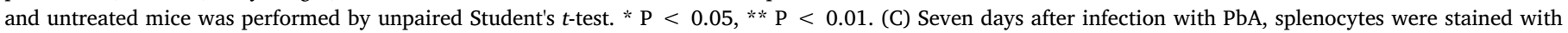

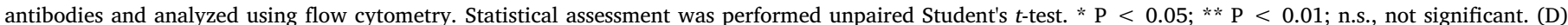

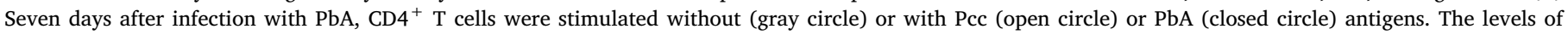

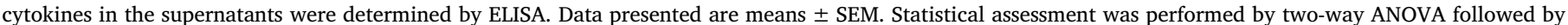

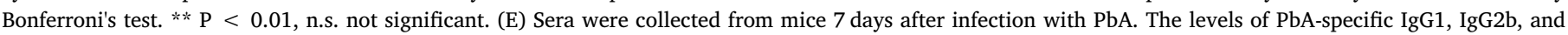
IgG2c antibodies in the sera were determined by ELISA. Statistical assessment was performed by unpaired Student's $t$-test. n.s., not significant.

IFN- $\gamma$ and TNF- $\alpha$ [35-37]. Furthermore, infection with Pcc, which did not induce severe brain damage in wild-type mice, induced symptoms and pathology similar to ECM with cerebral edema and hemorrhage in IL-10 ${ }^{-/-}$B6 mice [38]. Moreover, PbA infection combined with IL-10R blockade induced increased incidence of ECM in BALB/c mice, which normally do not develop ECM [39]. In our model of Pcc-primed PbAinfected mice, parasitemia levels were inhibited in IL-10-blocked mice, indicating a critical role of IL-10 in inhibiting the protective immune responses against $\mathrm{PbA}$. The proportion of activated $\mathrm{CD} 4^{+} \mathrm{T}$ cells significantly increased, while the proportion of activated $\mathrm{CD}^{+}{ }^{+} \mathrm{T}$ cells did not. The proportion of $\gamma \delta$ T cells and B cells also increased, while levels of serum anti-Plasmodium antibodies were unchanged, and the proportion of NK cells was reduced in IL-10R-blocked mice. These results suggest that enhanced clonal expansion and IFN- $\gamma$ production of specific $\mathrm{CD}^{+}$and $\gamma \delta \mathrm{T}$ cell subsets is the main driving force for the inhibition of parasitemia in IL-10R-blocked mice. This is consistent with previous studies that suggest a critical role of both $\mathrm{CD} 4^{+}$and $\gamma \delta \mathrm{T}$ cells in the protective immunity against blood-stage infection with Pcc [6,40,41]. In addition, $\gamma \delta \mathrm{T}$ cells express CD40L and activate dendritic cells via CD40 signaling, resulting in increased activation of $\alpha \beta$ T cells in the $P$. berghei XAT infection model [42]. In contrast to the primed mice, parasitemia levels in unprimed mice was not significantly affected by IL- 10 blockade after PbA infection, and the proportion of $\gamma \delta \mathrm{T}$ cell was not increased. In these mice, production of IFN- $\gamma$ by $\mathrm{CD}^{+} \mathrm{T}$ 
A

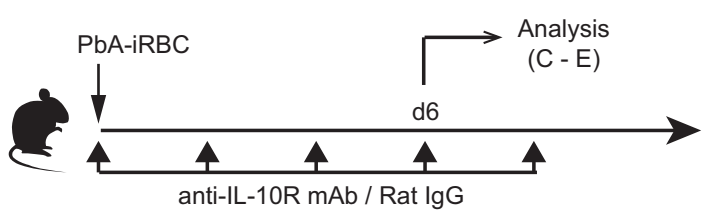

B
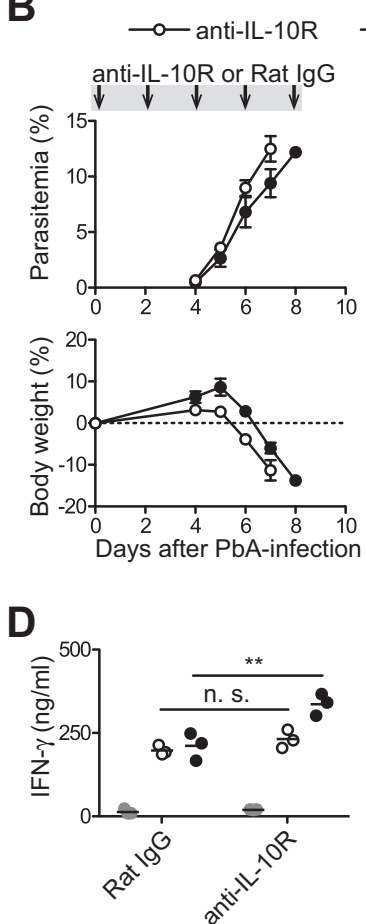
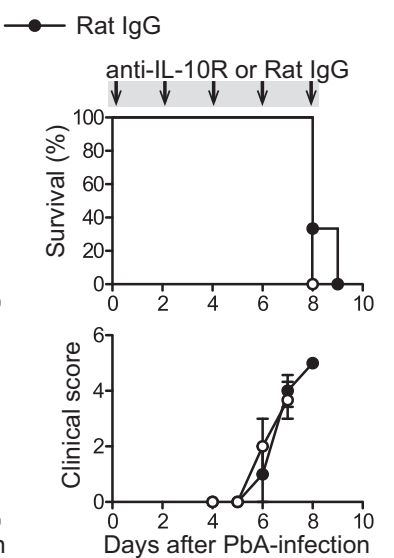

E

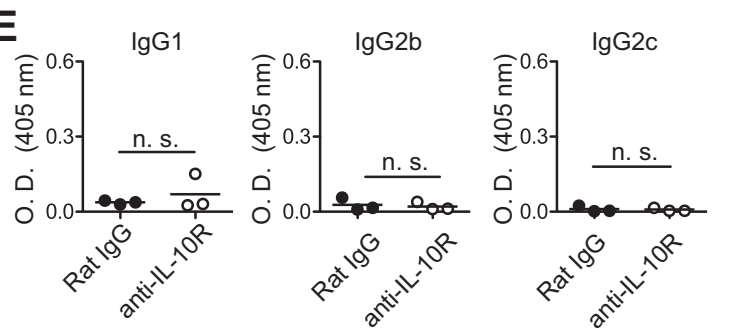

C $\mathrm{CD4}^{+} \mathrm{T}$ cells
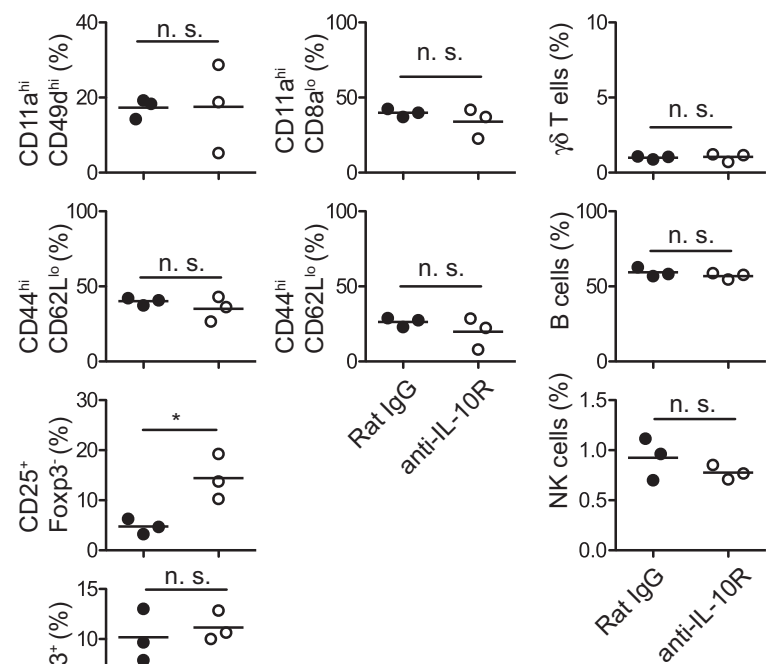

CD8 ${ }^{+} \mathrm{T}$ cells
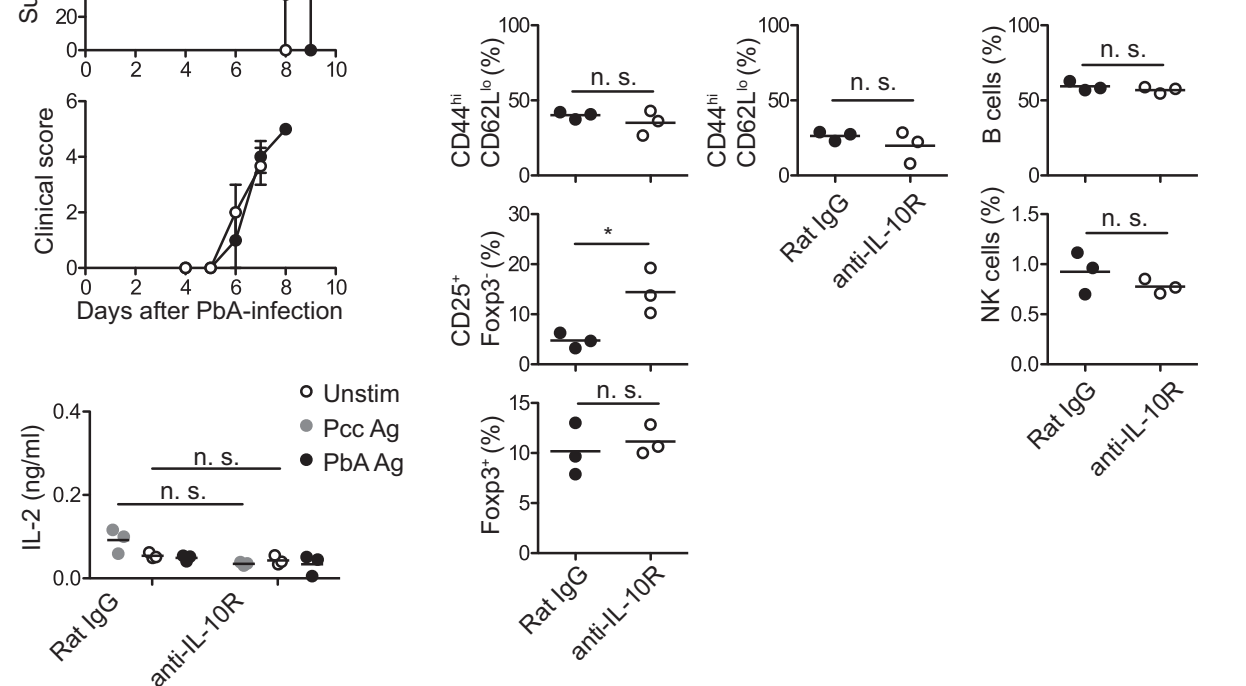
A

Day 6 treat

Day 14 treat
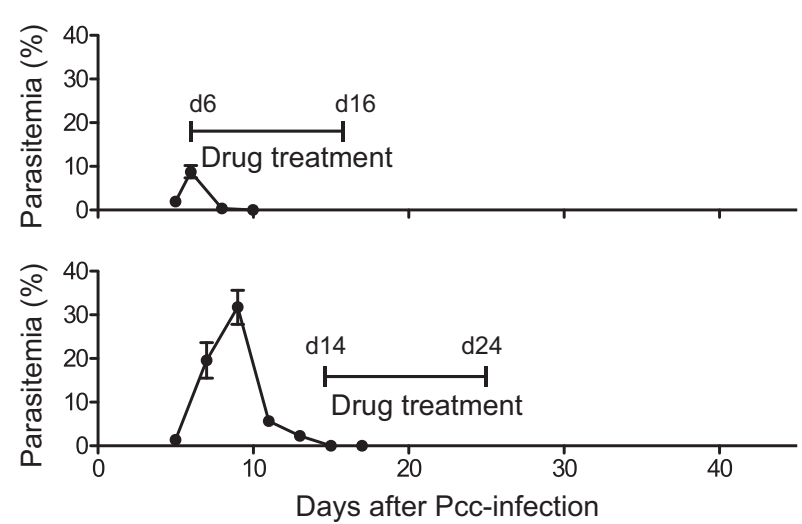

B

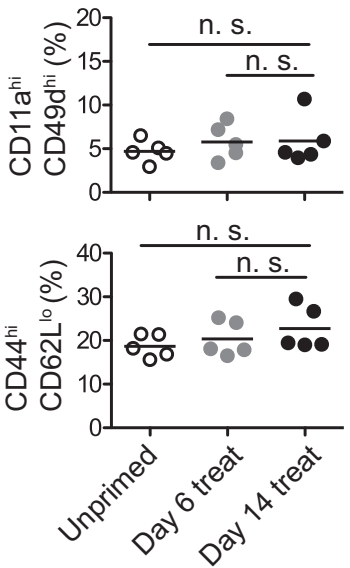

C

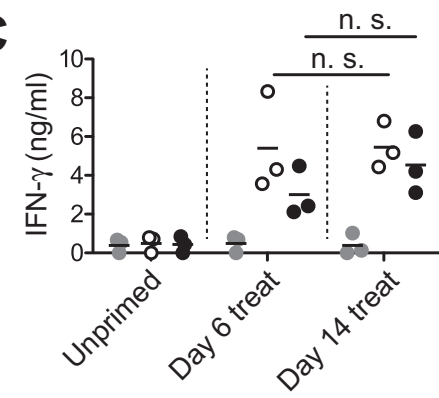

D

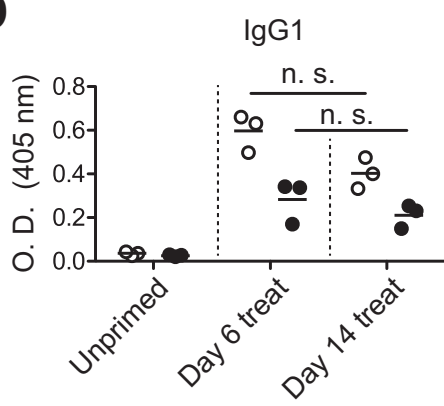

E
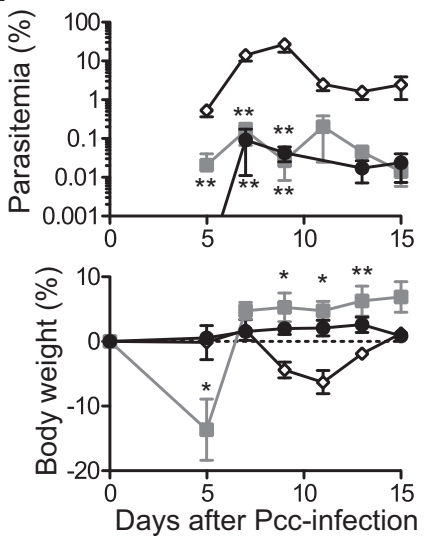
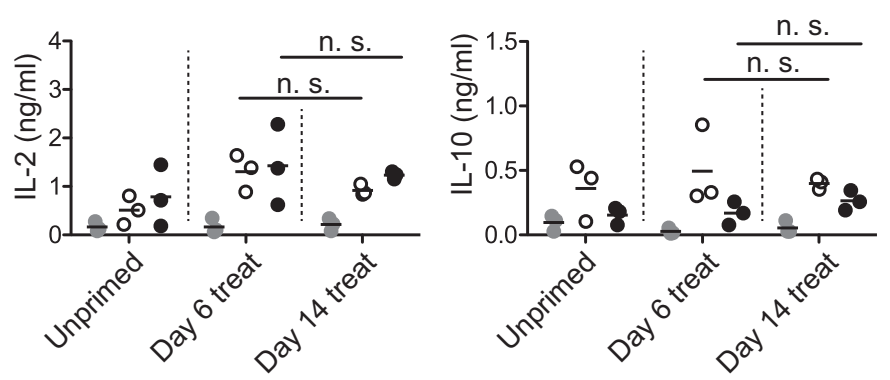

$\lg G 2 b$
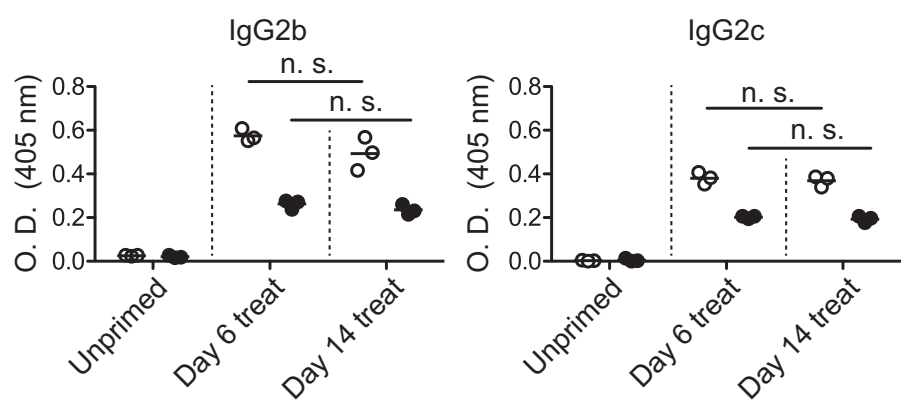

$\mathbf{F}$
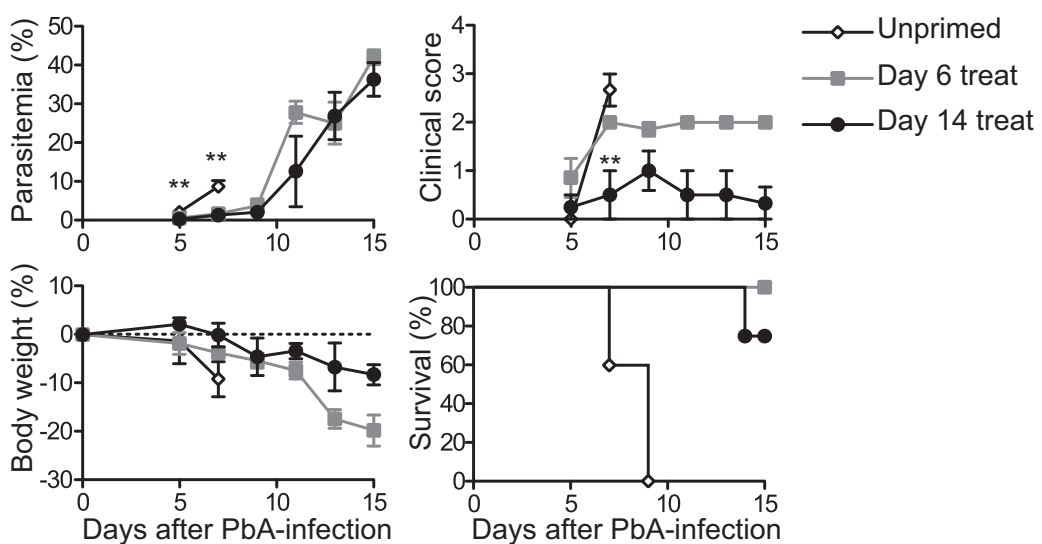

- Pcc Ag

- PbAAg
- Unstim

- Pcc Ag

- $\mathrm{PbAAg}$ 


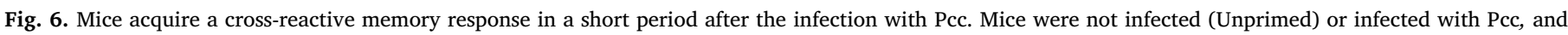

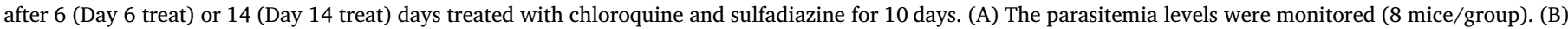

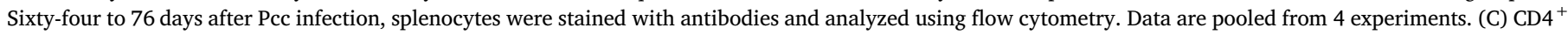

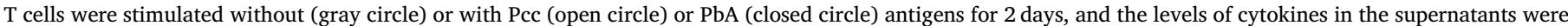

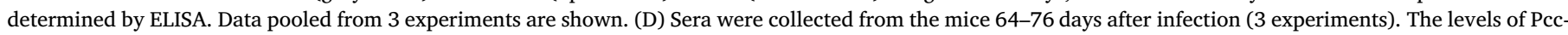

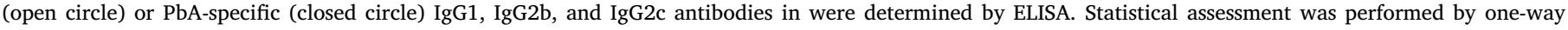

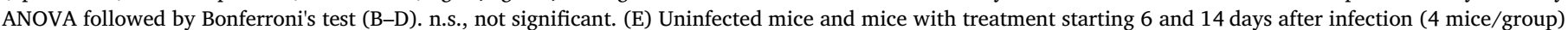

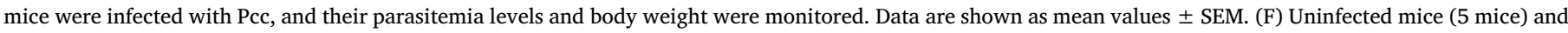

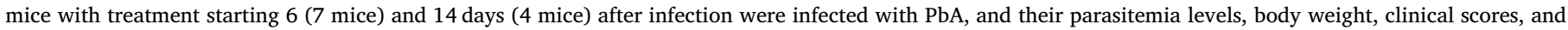

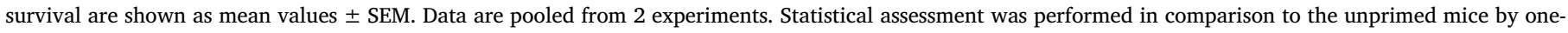
way ANOVA followed by Bonferroni's test (E, F). ${ }^{* *} \mathrm{P}<0.01,{ }^{*} \mathrm{P}<0.05$.

infections; however, further research is required to identify these specific parameters.

An increasing body of evidence indicates that T-cell-derived IL-10 is critical for downregulating inflammatory pathology during blood-stage Plasmodium infection [43]. Our study showed that IL-10 plays a pivotal role in inhibiting the protective immune response against secondary infection with heterologous parasites. When the protective memory immune response is strong enough, IL-10 may protect the host from pathology induced by an excessive immune response. We suspect, however, that when the host is infected with heterologous parasites, cross-reactive immunity may not be sufficiently powerful, and IL-10 may inhibit the protection. In malaria-endemic areas, multiple strains and species of Plasmodium parasites are present, and IL-10 may have a regulatory role in both protection and pathology, depending on the combination of the immune response and types of parasites. These features highlight the importance of IL-10 in balancing the protective and pathogenic immune responses and suggest that IL-10 may influence different outcomes, depending on the present parasite strains.

\section{Acknowledgements}

We thank Dr. R. Culleton providing Pcc and Dr. M. Yuda for providing $\mathrm{PbA}$ and PbA-GFP. We also thank Dr. K. Kimura for animal care.

\section{Funding sources}

This work was supported by grants-in-aid for scientific research from Japan Society for the Promotion of Science (16H05183) to K.Y.

\section{Appendix A. Supplementary data}

Supplementary data to this article can be found online at https:// doi.org/10.1016/j.parint.2019.01.003.

\section{References}

[1] World Health Organization, World Malaria Report 2018, World Health Organization, 2018.

[2] M.F. Good, H. Xu, M. Wykes, C.R. Engwerda, Development and regulation of cellmediated immune responses to the blood stages of malaria: implications for vaccine research, Annu. Rev. Immunol. 23 (2005) 69-99.

[3] E.M. Riley, V.A. Stewart, Immune mechanisms in malaria: new insights in vaccine development, Nat. Med. 19 (2) (2013) 168-178.

[4] P.D. Crompton, J. Moebius, S. Portugal, M. Waisberg, G. Hart, L.S. Garver, L.H. Miller, C. Barillas-Mury, S.K. Pierce, Malaria immunity in man and mosquito: insights into unsolved mysteries of a deadly infectious disease, Annu. Rev. Immunol. 32 (2014) 157-187.

[5] D. Perez-Mazliah, J. Langhorne, CD4 T-cell subsets in malaria: TH1/TH2 revisited, Front. Immunol. 5 (2014) 671.

[6] S. Inoue, M. Niikura, S. Mineo, F. Kobayashi, Roles of IFN- $\gamma$ and $\gamma \delta$ T Cells in protective Immunity against Blood-Stage Malaria, Front. Immunol. 4 (2013) 258.

[7] S.S. Struik, E.M. Riley, Does malaria suffer from lack of memory? Immunol. Rev. 201 (2004) 268-290.

[8] L. Schofield, G.E. Grau, Immunological processes in malaria pathogenesis, Nat. Rev. Immunol. 5 (9) (2005) 722-735.

[9] C. Engwerda, E. Belnoue, A.C. Gruner, L. Renia, Experimental models of cerebral malaria, Curr. Top. Microbiol. Immunol. 297 (2005) 103-143.

[10] S.W. Howland, C.M. Poh, S.Y. Gun, C. Claser, B. Malleret, N. Shastri, F. Ginhoux, G.M. Grotenbreg, L. Renia, Brain microvessel cross-presentation is a hallmark of experimental cerebral malaria, EMBO Mol. Med. 5 (7) (2013) 984-999.

[11] J. Nitcheu, O. Bonduelle, C. Combadiere, M. Tefit, D. Seilhean, D. Mazier, B. Combadiere, Perforin-dependent brain-infiltrating cytotoxic CD8 ${ }^{+} \mathrm{T}$ lymphocytes mediate experimental cerebral malaria pathogenesis, J. Immunol. 170 (4) (2003) 2221-2228.

[12] E. Belnoue, M. Kayibanda, A.M. Vigario, J.C. Deschemin, N. van Rooijen, M. Viguier, G. Snounou, L. Renia, On the pathogenic role of brain-sequestered $\alpha \beta$ $\mathrm{CD}^{+}{ }^{+} \mathrm{T}$ cells in experimental cerebral malaria, J. Immunol. 169 (11) (2002) 6369-6375.

[13] A. Villegas-Mendez, R. Greig, T.N. Shaw, J.B. de Souza, E. Gwyer Findlay, J.S. Stumhofer, J.C. Hafalla, D.G. Blount, C.A. Hunter, E.M. Riley, K.N. Couper, IFN$\gamma$-producing $\mathrm{CD}^{+}{ }^{+} \mathrm{T}$ cells promote experimental cerebral malaria by modulating $\mathrm{CD}^{+}{ }^{+} \mathrm{T}$ cell accumulation within the brain, J. Immunol. 189 (2) (2012) 968-979.

[14] M. Inoue, J. Tang, M. Miyakoda, O. Kaneko, K. Yui, R. Culleton, The species specificity of immunity generated by live whole organism immunisation with erythrocytic and pre-erythrocytic stages of rodent malaria parasites and implications for vaccine development, Int. J. Parasitol. 42 (9) (2012) 859-870.

[15] P.C. Bull, B.S. Lowe, M. Kortok, C.S. Molyneux, C.I. Newbold, K. Marsh, Parasite antigens on the infected red cell surface are targets for naturally acquired immunity to malaria, Nat. Med. 4 (3) (1998) 358-360.

[16] P.C. Bull, A. Pain, F.M. Ndungu, S.M. Kinyanjui, D.J. Roberts, C.I. Newbold, K. Marsh, Plasmodium falciparum antigenic variation: relationships between in vivo selection, acquired antibody response, and disease severity, J. Infect. Dis. 192 (6) (2005) 1119-1126.

[17] W. Jarra, K.N. Brown, Protective immunity to malaria: studies with cloned lines of Plasmodium chabaudi and P. berghei in CBA/Ca mice. I. the effectiveness and interand intra-species specificity of immunity induced by infection, Parasite Immunol. 7 (6) (1985) 595-606.

[18] S. Cheesman, A. Raza, R. Carter, Mixed strain infections and strain-specific protective immunity in the rodent malaria parasite Plasmodium chabaudi chabaudi in mice, Infect. Immun. 74 (5) (2006) 2996-3001.

[19] A. Ouattara, A.E. Barry, S. Dutta, E.J. Remarque, J.G. Beeson, C.V. Plowe, Designing malaria vaccines to circumvent antigen variability, Vaccine 33 (52) (2015) $7506-7512$.

[20] S.R. Elliott, R.D. Kuns, M.F. Good, Heterologous immunity in the absence of variantspecific antibodies after exposure to subpatent infection with blood-stage malaria, Infect. Immun. 73 (4) (2005) 2478-2485.

[21] M.F. Good, J.M. Reiman, I.B. Rodriguez, K. Ito, S.K. Yanow, I.M. El-Deeb, M.R. Batzloff, D.I. Stanisic, C. Engwerda, T. Spithill, S.L. Hoffman, M. Lee, V. McPhun, Cross-species malaria immunity induced by chemically attenuated parasites, J. Clin. Invest. 123 (2013) 3353-3362.

[22] R. Stephens, R.L. Culleton, T.J. Lamb, The contribution of Plasmodium chabaudi to our understanding of malaria, Trends Parasitol. 28 (2) (2012) 73-82.

[23] J.L. Grun, W.P. Weidanz, Immunity to Plasmodium chabaudi adami in the B-celldeficient mouse, Nature 290 (5802) (1981) 143-145.

[24] J.L. Grun, W.P. Weidanz, Antibody-independent immunity to reinfection malaria in B-cell-deficient mice, Infect. Immun. 41 (3) (1983) 1197-1204.

[25] T. Tamura, K. Kimura, M. Yuda, K. Yui, Prevention of experimental cerebral malaria by Flt3 ligand during infection with Plasmodium berghei ANKA, Infect. Immun. 79 (10) (2011) 3947-3956.

[26] F.H. Amante, A.C. Stanley, L.M. Randall, Y. Zhou, A. Haque, K. McSweeney, A.P. Waters, C.J. Janse, M.F. Good, G.R. Hill, C.R. Engwerda, A role for natural regulatory $\mathrm{T}$ cells in the pathogenesis of experimental cerebral malaria, Am. J. Pathol. 171 (2) (2007) 548-559.

[27] D. Kimura, M. Miyakoda, K. Honma, Y. Shibata, M. Yuda, Y. Chinzei, K. Yui, Production of IFN- $\gamma$ by $\mathrm{CD}^{+}{ }^{+} \mathrm{T}$ cells in response to malaria antigens is IL- 2 dependent, Int. Immunol. 22 (12) (2010) 941-952.

[28] D.S. McDermott, S.M. Varga, Quantifying antigen-specific CD4 T cells during a viral infection: CD4 T cell responses are larger than we think, J. Immunol. 187 (11) (2011) 5568-5576.

[29] N.S. Butler, J. Moebius, L.L. Pewe, B. Traore, O.K. Doumbo, L.T. Tygrett, T.J. Waldschmidt, P.D. Crompton, J.T. Harty, Therapeutic blockade of PD-L1 and LAG-3 rapidly clears established blood-stage Plasmodium infection, Nat. Immunol. 13 (2) (2011) 188-195.

[30] S.W. Howland, C. Claser, C.M. Poh, S.Y. Gun, L. Renia, Pathogenic CD8 ${ }^{+}$T cells in experimental cerebral malaria, Semin. Immunopathol. 37 (3) (2015) 221-231.

[31] S. Kossodo, C. Monso, P. Juillard, T. Velu, M. Goldman, G.E. Grau, Interleukin-10 modulates susceptibility in experimental cerebral malaria, Immunology 91 (4) (1997) 536-540.

[32] K.W. Moore, R. de Waal Malefyt, R.L. Coffman, A. O'Garra, Interleukin-10 and the 
interleukin-10 receptor, Annu. Rev. Immunol. 19 (2001) 683-765.

[33] C.L. Maynard, C.T. Weaver, Diversity in the contribution of interleukin-10 to T-cellmediated immune regulation, Immunol. Rev. 226 (2008) 219-233.

[34] A. Joss, M. Akdis, A. Faith, K. Blaser, C.A. Akdis, IL-10 directly acts on T cells by specifically altering the CD28 co-stimulation pathway, Eur. J. Immunol. 30 (6) (2000) 1683-1690.

[35] A. Linke, R. Kuhn, W. Muller, N. Honarvar, C. Li, J. Langhorne, Plasmodium chabaudi chabaudi: differential susceptibility of gene-targeted mice deficient in IL-10 to an erythrocytic-stage infection, Exp. Parasitol. 84 (2) (1996) 253-263.

[36] C. Li, I. Corraliza, J. Langhorne, A defect in interleukin-10 leads to enhanced malarial disease in Plasmodium chabaudi chabaudi infection in mice, Infect. Immun. 67 (9) (1999) 4435-4442.

[37] C. Li, L.A. Sanni, F. Omer, E. Riley, J. Langhorne, Pathology of Plasmodium chabaudi chabaudi infection and mortality in interleukin-10-deficient mice are ameliorated by anti-tumor necrosis factor $\alpha$ and exacerbated by anti-transforming growth factor $\beta$ antibodies, Infect. Immun. 71 (9) (2003) 4850-4856.

[38] L.A. Sanni, W. Jarra, C. Li, J. Langhorne, Cerebral edema and cerebral hemorrhages in interleukin-10-deficient mice infected with Plasmodium chabaudi, Infect. Immun. 72 (5) (2004) 3054-3058.

[39] C. Claser, J.B. De Souza, S.G. Thorburn, G.E. Grau, E.M. Riley, L. Renia, J.C.R. Hafalla, Host resistance to Plasmodium-induced acute immune pathology is regulated by interleukin-10 receptor signaling, Infect. Immun. 85 (6) (2017).

[40] H.C. van der Heyde, M.M. Elloso, W.L. Chang, M. Kaplan, D.D. Manning, W.P. Weidanz, $\gamma \delta \mathrm{T}$ cells function in cell-mediated immunity to acute blood-stage Plasmodium chabaudi adami malaria, J. Immunol. 154 (8) (1995) 3985-3990.

[41] H.C. van der Heyde, J.M. Batchelder, M. Sandor, W.P. Weidanz, Splenic $\gamma \delta$ T cells regulated by $\mathrm{CD}^{+}{ }^{+} \mathrm{T}$ cells are required to control chronic Plasmodium chabaudi malaria in the B-cell-deficient mouse, Infect. Immun. 74 (5) (2006) 2717-2725.

[42] S. Inoue, M. Niikura, S. Takeo, S. Mineo, Y. Kawakami, A. Uchida, S. Kamiya,
F. Kobayashi, Enhancement of dendritic cell activation via CD40 ligand-expressing $\gamma \delta$ T cells is responsible for protective immunity to Plasmodium parasites, Proc. Natl. Acad. Sci. U. S. A. 109 (30) (2012) 12129-12134.

[43] A.P. Freitas do Rosario, J. Langhorne, T cell-derived IL-10 and its impact on the regulation of host responses during malaria, Int. J. Parasitol. 42 (6) (2012) $549-555$.

[44] A. Villegas-Mendez, T.N. Shaw, C.A. Inkson, P. Strangward, J.B. de Souza, K.N. Couper, Parasite-specific CD $4^{+} \mathrm{IFN}-\gamma^{+} \mathrm{IL}-10^{+} \mathrm{T}$ cells distribute within both lymphoid and nonlymphoid compartments and are controlled systemically by interleukin-27 and ICOS during blood-stage malaria infection, Infect. Immun. 84 (1) (2016) 34-46.

[45] A. Villegas-Mendez, C.A. Inkson, T.N. Shaw, P. Strangward, K.N. Couper, LongLived $\mathrm{CD} 4{ }^{+} \mathrm{IFN}_{-}{ }^{+}{ }^{+} \mathrm{T}$ cells rather than short-Lived $\mathrm{CD} 4^{+} \mathrm{IFN}-\gamma^{+} \mathrm{IL}_{-}-10^{+} \mathrm{T}$ cells initiate rapid IL-10 production to suppress anamnestic T cell responses during secondary malaria infection, J. Immunol. 197 (8) (2016) 3152-3164.

[46] P. Jagannathan, I. Eccles-James, K. Bowen, F. Nankya, A. Auma, S. Wamala, C. Ebusu, M.K. Muhindo, E. Arinaitwe, J. Briggs, B. Greenhouse, J.W. Tappero, M.R. Kamya, G. Dorsey, M.E. Feeney, IFN $\gamma / \mathrm{IL}-10$ co-producing cells dominate the CD4 response to malaria in highly exposed children, PLoS Pathog. 10 (1) (2014) e1003864.

[47] S. Portugal, J. Moebius, J. Skinner, S. Doumbo, D. Doumtabe, Y. Kone, S. Dia, K. Kanakabandi, D.E. Sturdevant, K. Virtaneva, S.F. Porcella, S. Li, O.K. Doumbo, K. Kayentao, A. Ongoiba, B. Traore, P.D. Crompton, Exposure-dependent control of malaria-induced inflammation in children, PLoS Pathog. 10 (4) (2014) e1004079.

[48] M.J. Boyle, P. Jagannathan, K. Bowen, T.I. McIntyre, H.M. Vance, L.A. Farrington, A. Schwartz, F. Nankya, K. Naluwu, S. Wamala, E. Sikyomu, J. Rek, B. Greenhouse, E. Arinaitwe, G. Dorsey, M.R. Kamya, M.E. Feeney, The development of Plasmodium falciparum-specific IL10 CD4 T cells and protection from malaria in children in an area of high malaria transmission, Front. Immunol. 8 (2017) 1329. 